\title{
Pemberdayaan Satgas Gotong Royong Berbasis Desa Adat Dalam Pencegahan COVID-19 di Banjar Serongga Pondok, Tabanan
}

\author{
Putu Nita Cahyawati ${ }^{*}$, A. A. Sri Agung Aryastuti ${ }^{1}$, Luh Gde Evayanti ${ }^{2}$ \\ ${ }^{I}$ Bagian Farmakologi dan Farmasi, Fakultas Kedokteran dan Ilmu Kesehatan, \\ Universitas Warmadewa \\ ${ }^{2}$ Bagian Anatomi dan Histologi Fakultas Kedokteran dan Ilmu Kesehatan, Universitas Warmadewa \\ *Email: putunitacahyawati@gmail.com
}

\begin{abstract}
[Empowerment Satgas Gotong Royong Berbasis Desa Adat to Prevent COVID-19 di Banjar Serongga Pondok, Tabanan]
\end{abstract}

The COVID-19 pandemic is affecting all elements of Indonesian society. Lack of knowledge, lack of readiness, and insufficient allocation of funds make the prevention of this disease a challenge for the entire community. Social distancing, limiting all activities outside the home, using masks, hand sanitizers and disinfectants are all efforts that can be made to prevent the spread of this disease. Banjar Serongga Pondok is one of the traditional Banjar which is quite consistent in implementing these things. The residents of Banjar Serongga Pondok have indeed tried to reduce all activities outside the home, but it is undeniable that there are still residents who have not been able to implement this properly. Therefore, a special task force was formed called the Satgas Gotong Royong Berbasis Desa Adat as the driving force for all COVID-19 virus prevention activities in Banjar. The routine efforts that usually they do are spraying disinfectant liquid every Sunday. However, the limitations of disinfectant fluids and budget constraints in the implementation of these activities made it difficult to carry out the activities. The condition, exacerbated by the scarcity of masks, also made it difficult for the task force to work for residents. Based on these problems, the service is focused on providing information related to COVID-19, providing masks, hand sanitizers, and disinfectants to the COVID-19 Task Force in Banjar Serongga Pondok. The activity was started by giving a speech by Kelian Adat Banjar Serongga Pondok, remarks by the head of the activity organizer, material delivery and discussion, the delivery of assistance, and assistance in the implementation of disinfection. This program is expected to help the task force's work program continuity in preventing the transmission of COVID-19, especially in Banjar Serongga Pondok.

Keywords: Empowerment, COVID-19, hand sanitizer, mask, Bali

\section{PENDAHULUAN}

Coronavirus disease 2019 (COVID-19) merupakan virus baru yang pertama kali ditemukan di Wuhan, China pada tahun 2019. Hingga tanggal 2 Maret 2020 virus ini sudah menginfeksi 90.308 dengan jumlah kematian 
mencapai 3.087 orang atau 6\%, dan jumlah pasien yang sembuh 45.726 orang. ${ }^{1}$

Gejala-gejala terinfeksi COVID-19 bervariasi mulai dari ringan sampai berat. Gejala biasanya muncul 2- 14 hari setelah terpapar virus. Gejala yang biasa dialami antara lain: demam, batuk, sesak napas, lemah, nyeri otot, sakit kepala, kehilangan indra penciuman (pengidu/smell) dan perasa (taste), sakit tenggorokan, hidung tersumbat atau berair (runny nose), mual, muntah, dan diare. ${ }^{2}$ Organisasi kesehatan dunia atau World Health Organization (WHO) merekomendasaikan penggunaa masker dengan benar sebagai salah satu upaya pencegahan virus ini..$^{3,4}$

Di Bali hingga saat ini ditemukan ada 222 kasus positif, 57 kasus transmisi loka, 105 pasien dirawat, 113 pasen sembuh dan 4 meninggal dunia. Sedangkan, di Kabupaten Tabanan tercatat ada 9 kasus positif, 2 dirawat di BRSU Tabanan dan 7 kasus sembuh. Terdapat 351 kasus Orang Dalam Pengawasan (ODP). Semua adalah warga negara Indonesia. Peningkatan kasus dan datangnya Pekerja Migran Indonessi (PMI) membuat Gubernur Bali, Wayan Koster mengeluarkan Instruksi Gubernur bernomor 412.2/2018/PPDA/PMA. Instruksi tersebut berisi perintah kepada Desa Adat untuk mendata pekerja migran yang baru pulang. Hingga kini, kasus impor masih mendominasi pasien positif di Bali. Pendataan itu bertujuan untuk mengantisipasi penyebaran virus corona (COVID-19) yang mungkin dibawa pekerja migran atau warga yang baru kembali dari luar Bali. ${ }^{5-8}$

\section{Banjar Serongga Pondok terletak di} Kabupaten Tabanan. Desa ini terdiri dar 74 kepala keluarga. Berdasarkan observasi dan wawancara yang dilakukan oleh tim pengabdi, masyarakat banjar Serongga pondok sudah membentuk satgas khusus yang bertugas untuk mengkoordinasikan segala usaha untuk mencegah meluasnya pandemi COVID-19 khususnya di wilayah banjarnya. Satgas yang dibentuk bernama Satgas Gotong Royong Berbasis Desa Adat. Berdasarkan penuturan ketua satgas, selama ini banjar telah mengupayakan agar warga membatasi segala aktivitas di luar rumah, serta melakukan penyemprotan desinfektan secara berkala yaitu 1 minggu sekali setiap hari Minggu. Kegiatan ini melibatkan pemuda desa yang diminta bantuan untuk masuk ke rumah-warga dan melakukan kegiatan desinfeksi tersebut. Walaupun demikian, warga kesulitan mendapatkan masker karena tidak ada apotik maupun penjual masker di banjar tersebut. Cairan desinfeksi juga sulit diperoleh. Hal ini tentunya semakin memberatkan satgas karena kasus COVID-19 juga terus bertambah. Kas atau simpanan dana satgas yang diperoleh melalui hasil sumbangan banjar juga semakin menipis guna memenuhi dan menjaga keberlangsungan program tersebut. Pekerjaan yang terbatas, biaya hidup yang tetap tinggi tidak memungkinkan satgas untuk meminta sumbangan warga lagi.

\section{METODE}

Metode pelaksanaan yang diterapkan diantaranya 
1. Pemberian informasi (penyuluhan) dan diskusi terkait pencegahan COVID-19. Informasi diberikan oleh narasumber tetang perkembangan COVID-19 di Bali dan di Indosesia serta pencegahan yang dapat dilakukan guna mencegah penularan virus ini. Pemberian penyuluhan ini diikuti oleh diskusi bersama aparatur desa, satgas dan perwakilan pemuda pemudi banjar.

2. Penyerahan bantuan berupa masker kain, handsanitizer dan desinfektan. Pada kegiatan ini juga diajarkan cara mengencerkan cairan desinfektn tersebut sebelum digunakan bahan-bahan tersebut sebelum digunakan.

3. Pendampingan pelaksanaan desinfeksi rutin setiap minggu. Kegiatan ini berkoordinasi dengan satgas dan perwakilan pemuda pemudi banjar.

4. Evaluasi program. Kegiatan ini dilakukan untuk menilai efektivitas program yang sudah dilakukan. Kegiatan berupa observasi langsung di lapangan serta melakukan diskusi dengan seluruh pihak untuk memperoleh informasi hambatan maupun kendala pelaksanaan kegiatan.

\section{HASIL DAN PEMBAHASAN}

Kegiatan pemberdayaan dan pendampingan melibatkan peran serta dari tim pelaksana dan mahasiswa FKIK Universitas Warmadewa. Mitra yang terlibat dalam kegiatan ini merupakan satgas covid 19 Banjar Serongga Pondok Desa Adat Bedha.

Kegiatan pengabdian dipandu oleh seorang moderator yang telah disiapkan oleh pihak banjar. Kegiatan diawali oleh pemberian sambutan oleh Kelian Adat Banjar Serongga Pondok, dilanjutkan oleh sambutan dari Ketua Pelaksana Kegiatan, penyampaian materi dan diskusi, penyerahan bantuan, serta pendampingan dalam pelaksanaan desinfeksi. Berikut merupakan paparan kegiatan:

a. Persiapan dan Pembukaan Kegiatan Kegiatan dilaksanakan pada hari Sabtu, 23 Mei 2020 bertempat di Bale Banjar Serongga Pondok, Kerambitan, Tabanan. Persiapan diawali dengan pemasangan LCD, laptop, pengeras suara, merapikan meja dan kursi dengan jarak kurang lebih 1 meter sesuai protokol kesehatan yang ditetapkan. Seluruh proses ini sepenuhnya dibantu oleh pihak banjar. Kegiatan dilanjutkan dengan sambutan oleh Bapak Ir. Ketut Sadia selaku Kelian Adat Banjar Serongga Pondok yang sekaligus membuka acara pada hari tersebut.

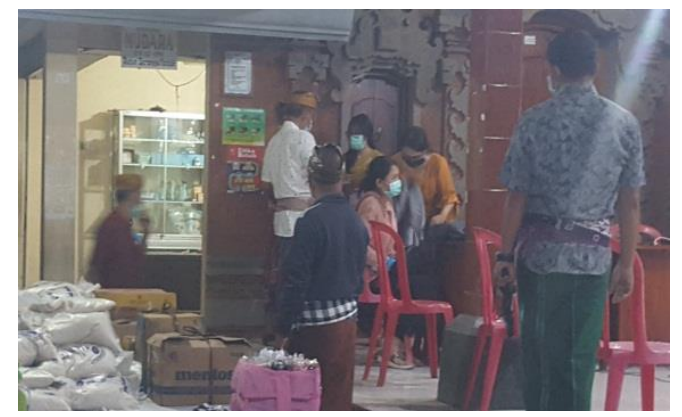

Gambar 1. Koordinasi sebelum Pelaksanaan Kegiatan 
https://ejournal.warmadewa.ac.id/index.php/wicaksana

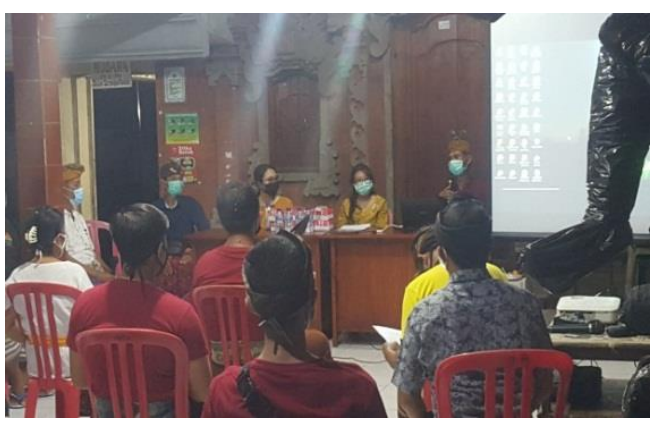

Gambar 2. Pembukaan Kegiatan oleh Kelian Adat Banjar Serongga Pondok

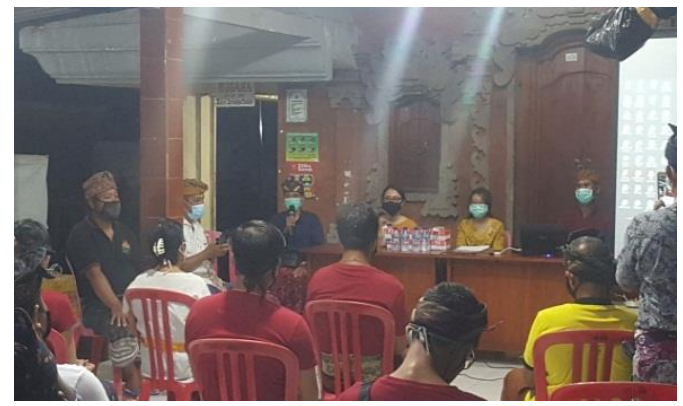

Gambar 3. Sambutan dari Ketua Satgas

COVID-19 Banjar Serongga Pondok

\section{b. Penyampaian Materi dan Diskusi}

Kegiatan dilaksanakan tepat pada pukul 19.00 WITA sesuai dengan waktu yang disepakati sebelumnya. Mengacu pada protokol kesehatan yang ada, jumlah peserta yang hadir dibatasi. Kegiatan hanya dihadiri oleh Bapak Ir. Ketut Sadia selaku Kelian Adat, Bapak Drs. I Nyoman Widiadnyana selaku Ketua Satgas, Jero Mangku I Made Suartana selaku Mangku di Balai Banjar (Pura Marda Tiga), Bapak I Kade Pendi Adnyana Putra selaku Ketua STT, Ketua Pecalang, juru arah adat, dan beberapa perwakilan anggota satgas serta STT. Total peserta yang dilibatkan pada kegiatan ini sejumlah 20 orang.
Penyampaian materi diberikan oleh tim pelaksana yaitu dr. Putu Nita Cahyawati, M.Sc dan dr. Luh Gde Evayanti, M.Si. Materi yang diberikan terkait dengan COVID-19 dan upayaupaya pencegahan yang dapat dilakukan guna terhindar dari infeksi virus tersebut. Tim pelaksana juga menginformasikan cara pembuatan cairan desinfektan sebelum digunakan dalam kegiatan penyemprotan rutin setiap minggunya.

Pada saat penyampaian materi, peserta kegiatan diberikan kesempatan untuk menyampaikan pertanyaan terkait hal-hal praktis dalam kehidupan sehari-hari yang berisiko untuk terinfeksi serta hal-hal yang harus dilakukan. Salah satu pertanyaan yang ditanyakan yaitu Apakah bensin bisa digunakan sebagaai cairan desinfeksi untuk memusnahkan virus COVID-19? Pertanyaan ini disampaikan oleh anggota satgas yang sehari-harinya bekerja di bengkel motor.

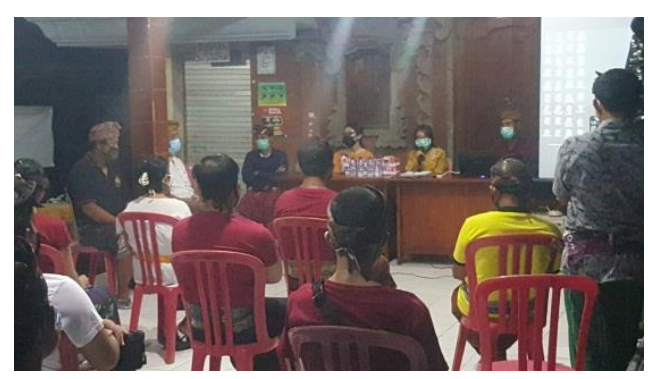

Gambar 4. Penyampaian Materi dan

Diskusi

c. Pemberian Bantuan

Pada kegiatan ini, tim pelaksana juga memberikan bantuan berupa 300 buah 
masker kain, 200 liter cairan desinfektan, dan 30 liter hand sanitizer. Bantuan ini diterima secara simbolis oleh Kelian Adat dan Ketua STT yang juga merupakan anggota satgas COVID-19 di Banjar Serongga Pondok. Pemberian sumbangan dibuktikan dengan penandatanganan dokumen serah terima barang yang telah dipersiapkan sebelumnya. Bantuan ini dirasakan sangat bermanfaat karena memang sangat diperlukan oleh pihak satgas guna melaksanakan program kerja rutinnya setiap minggu. Masker dan handsanitizer yang diberikan juga dibagikan secara merata kepada seluruh warga banjar.

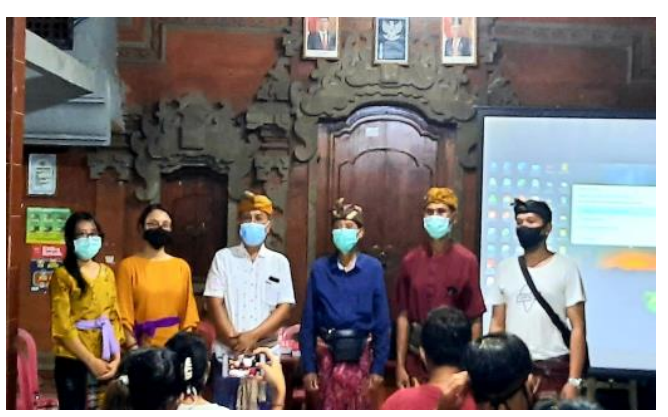

Gambar 5. Tim Pelaksana Beserta Kelian

Adat, Ketua Satgas dan Ketua STT Banjar Serongga Pondok, Kerambitan

d. Pendampingan

Pada proses ini, satgas COVID-19 didampingi oleh tim pada kegiatan rutin penyemprotan desinfektan setiap minggunya. Pelaporan oleh satgas kepada tim terkait kondisi di masyarakat dan permasalahan yang dihadapi secara konsisten dilakukan.

\section{Monitoring dan Evaluasi}

Setelah pelaksanakan kegiatan, diperoleh hasil sebagai berikut:

a. Persentase kehadiran dan keikutsertaan mitra pada kegiatan ini sangat baik. Jumlah peserta yang terlibat pada kegiatan ini yaitu 20 orang. Hasil ini sesuai dengan yang diharapkan yaitu $\geq 85 \%$.

b. Kegiatan sudah terlaksana dengan baik dinilai dari pelaksanaan kegiatan tepat waktu, keterlibatan dan kerjasama yang baik dari pihak desa dan tim pelaksana, ketersediaan alat dan bahan kegiatan yang memadai selama kegiatan, serta pelaksanaan kegiatan dan pendampingan yang juga berlangsung baik.

\section{KESIMPULAN}

Mitra terlibat secara aktif dalam pelaksanaan kegiatan pengabdian dengan persentase kehadiran sebesar 100\%. Program sudah terlaksana dengan baik dinilai dari pelaksanaan kegiatan tepat waktu, keterlibatan dan kerjasama yang baik dari pihak Banjar Serongga Pondok, tim Pelaksana, Mahasiswa FKIK Unwar, ketersediaan alat dan bahan kegiatan yang memadai selama kegiatan, serta pelaksanaan dan pendampingan yang juga berlangsung baik. 


\section{DAFTAR PUSTAKA}

1. Yuliana. 2020. Corona virus diseases (Covid-19): Sebuah tinjauan literatur. Wellness And Healthy Magazine. 2(1):187-92.

2. Center for Disease Control and Prevention. 2020. Symptoms of Coronavirus. Center for Disease Control and Prevention. Available at https://www.cdc.gov/coronavirus/2019ncov/symptoms-testing/symptoms.html

3. World Health Organization. (2020). Advice on the use of masks in the context of COVID-19: interim guidance, 6 April 2020. World Health

Organization. https://apps.who.int/iris/han dle/10665/331693.

4. WHO. Advice for public: When and How to use masks. https://www.who.int/emergencies/diseases Inovel-coronavirus-2019/advice-forpublic/when-and-how-to-use-masks. Accessed: 14 April 2020.

5. Dinas Kesehatan Provinsi Bali. Data Sebaran Kasus Covid-19 Sampai Dengan Tanggal 30 Apr 2020 di Bali (Bali). Available at: https://pendataan.baliprov.go.id/

6. Yonanto, R. Update Corona di Bali 30 April: 215 Positif, 96 Sembuh dan 4 Meninggal. Available at: https://bali.inews.id/berita/update-coronadi-bali-30-april-215-positif-96-sembuhdan-4-meninggal
7. Praptono, DW. BRSUD Tabanan Isolasi Dua Pekerja Migran Positif Corona Available at: https://radarbali.jawapos.com/read/2020/0 4/10/188245/brsud-tabanan-isolasi-duapekerja-migran-positif-corona

8. Sanjiwani, NKW. Pernah Rawat Pasien Positif COVID-19, Seorang Warga Tabanan Diisolasi. Available at: https://bali.idntimes.com/news/bali/niketut-wira-sanjiwani/update-fakta-wargatabanan-covid/full. 